\title{
Simulations of nitrogen dynamism in maize and rice by using CSM-CERES-maize and rice models under Chitwan, Nepal
}

\author{
TN Bhusal ${ }^{1}$, A Lamsal $^{2}$ and LP Amgain ${ }^{3}$ \\ ${ }^{1}$ IAAS Lamjung Campus, ${ }^{2}$ MS student, and ${ }^{3}$ IAAS Rampur Campus, Nepal
}

\begin{abstract}
Crop modeling is being popular in the field of agriculture as a precision tool for resources allocations and their effective utilizations. Two separate field and simulation studies were accomplished in maize and rice that were laid out in the two factor factorial randomized complete block design at Agronomy Farm of Institute of Agriculture and Animal Sciences, Rampur, Chitwan Nepal during spring and rainy season of 2007 and 2008, respectively. CERESmaize and rice models were calibrated using the best performing treatments $\left(7.41 \times 10^{4}\right.$ plants $/$ ha for all 3 varieties of maize i.e. Rampur Composite, Upahar and Arun 4 and $160 \mathrm{~kg} \mathrm{~N} /$ ha for Prithivi and Sunaulo Sugandha, and 120 $\mathrm{kg} \mathrm{N} /$ ha for Masuli varieties of rice). Models were validated using the remaining treatments $(6.36,5.56$ and $4.76 \mathrm{x}$ $10^{4}$ plants /ha for all varieties in maize and 40, 80 and $120 \mathrm{~kg} \mathrm{~N} / \mathrm{ha}$ for Prithivi and Sunaulo Sugandha and 40, 80 and $160 \mathrm{~kg} \mathrm{~N} / \mathrm{ha}$ for Mansuli in rice) to predict growth and productivity of different varieties of maize and rice. Model calibration was done with the determination of genetic coefficients and validation was accomplished with the comparison of observed and simulated values on anthesis days, maturity days, leaf area indices, above ground biomass at maturity, unit weight, and grain yields for both maize and rice. The simulation results on nitrogen dynamics revealed that the nitrification and leaching losses were higher under the conditions of non-flooded maize whereas ammonia volatilization and denitrification losses were higher in the conditions of alternately wetting and drying flooded rice field. The degree and magnitude of N-loss is higher when the N-level is advancing under both field conditions. However, volatilization was almost nil in the non-flooded maize. Results indicated that CERESmaize and rRice models could be applied in simulating the agronomic management options including the efficiency of $\mathrm{N}$-application under the conditions of availability of complete datasets required to run the Cropping System Models (CSM)-CERES-maize and rice models embedded under Decision Support System for Agro Technology Transfer (DSSAT) ver 4.2 in the coming days.
\end{abstract}

Keywords: CSM-CERES-Maize, CSM-CERES- Rice, Nitrogen dynamics, model evaluation

\section{Introduction}

Maize and rice are the major dominating and high valued cereals in the world, while rice--maize (RM) systems are of immense importance for food security in South Asia and it is replacing the rice-wheat and other winter crops (Timsina et al., 2010). Rice and maize are the most importantly prioritized major crops in Nepal as envisaged by the Agricultural Perspective Plan of Nepal (APP, 1995). In Nepal, the central terai occupies about 315090 ha rice and 42779 ha maize areas with the average productivity of 3148 and $2553 \mathrm{~kg} / \mathrm{ha}$, respectively (MoA/C, 2008/09). Similarly, rice (Oryza sativa L.) is the most important commodity in Nepalese agriculture and is grown in about 1.55 million ha $(50 \%$ of the total cultivated area during the spring and summer) producing 4.3 million tons of rough paddy with an average productivity of $2.78 \mathrm{t} / \mathrm{ha}$ (Sah, 2010). The share of rice is $20 \%$ to the agricultural gross domestic product (AGDP) in Nepal. However, the yield of both maize and rice is low behind the world average $(5.01 \mathrm{t} / \mathrm{ha}$ for maize and $4.23 \mathrm{t} /$ ha for rice (FAOSTAT, 2007). Among the various factors responsible for the lower production 
of maize low plant population, poor varietal choice vis-a-vis-fertilizer management tops the agenda (Gurung, 2010). Similarly, in rice, few of the main reasons for low yield is due to poor selection of varieties and low nitrogen use efficiency mismatching the ineffective splitting of $\mathrm{N}$ application These afore-mentioned yields are far behind the average world level yield and Nepalese farmers are facing the problems of food insecurity over the years. Being nearness to the developmental infrastructure source, the agriculture in these eco-zones is mainly affected by series of climatic anomalies and their induced effects like abiotic and biotic stresses (Amgain and Timsina, 2005). In spite the large research efforts to lift the system yields; there are still large gaps between biologically and climatically achievable potential yields and research station and on-farm yields (Timsina and Connor, 2001, Timsina et al., 2004, Amgain and Timsina, 2005).

Soils of South and South East Asian countries in which cereals are extensively grown are invariably deficit in $\mathrm{N}$ and poor organic matter. Inadequate nutrition, therefore, constitutes one of the major constraints to their production and $\mathrm{N}$ is the most limiting (De Datta, 1984). One half of the amount of $\mathrm{N}$ applied in rice is lost by volatilization and leaching. Ammonia volatilization is now recognized as a potentially important mechanism of fertilizer $\mathrm{N}$ loss in wetland rice fields, whereas nitrificationdenitrification has long been considered an important mechanism of $\mathrm{N}$ loss in flooded soils (Watanabe and Mitsui, 1979). Efficient fertilizer $\mathrm{N}$ management is thus important for increasing yield and $\mathrm{N}$ use efficiency, and reducing losses of $\mathrm{N}$ to the environment. This can be achieved by thorough knowledge of degree and magnitude of fate of applied $\mathrm{N}$-fertilizer, which in turn; can be quantified using the crop simulation models. Maize being the high dry matter producing crops, also exploits more nutrients and their management is felt necessary. The plant population during the spring is governing the major yield determining factor in maize.

Crop simulation models integrate the interdisciplinary knowledge gained through experimentation and technological innovation in the fields of biological, physical and chemical science relating to agricultural production system. This model, with well calibration and validation, has been used in the different region of world for the analysis of crop growth, development and nitrogen dynamism under different condition of soil. Asadi and Clement (2003) studied nitrogen dynamism by using CERES-Maize model and concluded that it may be applied with confidence to study the effects of $\mathrm{N}$ and irrigation management on maize yield, nitrate leaching and $\mathrm{N}$ uptake under irrigated tropical conditions. Similarly, Pathak et al. (2002); Amgain et al., (2006); and Amgain and Timsina (2007) evaluated the CERES-Rice model (ver. 4.0) for soil mineral $\mathrm{N}$ and loss processes from rice fields under RW systems for Delhi, Modipuram and Punjab in northwest India. In context of Nepal, the model had not been tested over different location of country except the few studies conducted, e.g., by Sapkota et al (2008) in winter maize. In this study we attempted to perform the study of CSM-CERES-Maize and CSM-CERES-Rice model to simulate the growth and yield of 3 cultivars of maize and rice each with different plant populations and Nitrogen levels under subtropical condition of southern central Nepal.

\section{Methodology}

Data from the field experiments on maize and rice conducted at Agronomy Farm of Institute of Agriculture and Animal Science, Rampur, Chitwan were first analyzed by MSTAT-C and ANOVA was used to evaluate the yield performance (Lamsal et al. 2010, Bhusal et al., 2008). Further the data were used to run CSM-CERES-Maize and Rice models. The best performed treatment was used for the calibration of the models under both crop situations. The treatment with $7.41 \times 10^{4}$ plants /ha for all three varieties of maize (Rampur Composite, Upahar and Arun-4) was used for calibration. During calibration, the genetic coefficients were determined for all three varieties as P1, P2, P5, G2, G3 and PHINT. These genetic coefficients were used for the validation with their respective variety. Validation was accomplished by comparison of model performance against data collected on $\mathrm{LAI}_{\max }$, days to anthesis and maturity, tops weight at maturity and grain yield for the remaining nine treatments (i.e. 6.36, 5.56 and 
$4.76 \times 10^{4}$ plants /ha for all three varieties). The density 6.36 plant /ha for all 3 varieties was used as the standard treatment for the nitrogen dynamism study in maize.

Similarly, CSM-CERES-Rice model was calibrated using $160 \mathrm{~kg} \mathrm{~N} / \mathrm{ha}$ for Prithivi and Sunaulo Sugandha and $120 \mathrm{~kg} \mathrm{~N} / \mathrm{ha}$ for Masuli. During calibration, the genetic coefficients were adjusted as P1, P2R, P5, P2O, G1, G2, G3 and G4. The P coefficients (P1, P2O, P2R, and P5) predict flowering and maturity, while the G coefficients (G1, G2, G3 and G4) represent the potential values under non-limiting condition. Once the genetic coefficients were adjusted, the calibrated coefficients values were used for the validation of model with their respective variety. Validation was done by using the data of the remaining nine treatments (i.e. 40, 80 and $120 \mathrm{~kg} \mathrm{~N} /$ ha for Prithivi and Sunaulo Sugandha and 40, 80 and $160 \mathrm{~kg} \mathrm{~N}$ /ha for Masuli) with the comparative study on the parameters as LAI $_{\max }$, days to anthesis and maturity, tops weight at maturity and grain yield. The $\mathrm{N}$-dose of $120 \mathrm{~kg} / \mathrm{ha}$ for all varieties was used as the standard treatment for the nitrogen dynamism study in rice.

\section{Results and discussion}

\section{Derivation of genetic coefficients}

The genetic coefficients were adjusted for three maize cultivars (Table 1) and for three rice cultivars (Table 2) by running the models several times by trial and error method. Genetic coefficient values of these varieties vary due to variation in growth and development rate at different phases. These estimated genetic coefficients were then used for validation and further analysis/ evaluation of the model. In case of maize, the simulated anthesis day, days to physiological maturity and grain yields for three cultivars were accurately found to be close to the observed values.

Table 1. Estimated genetic coefficients of maize varieties Rampur Composite, Upahar and Arun-4 under different plant densities during 2007 in Rampur

\begin{tabular}{lllllllllllll}
\hline Cultivars & \multicolumn{4}{c}{ Genetic coefficients } & \multicolumn{3}{c}{ Anthesis day } & \multicolumn{2}{c}{$\begin{array}{c}\text { Physiological } \\
\text { maturity day }\end{array}$} & \multicolumn{2}{c}{$\begin{array}{l}\text { Grain yield } \\
\text { (kg/ha) }\end{array}$} \\
\cline { 2 - 13 } & P1 & P2 & P5 & G2 & G3 & PHINT & Sim. & Obs. & Sim. & Obs. & Sim. & Obs. \\
\hline RC & 285.7 & 0.50 & 869.5 & 752.4 & 8.71 & 45 & 68 & 68 & 109 & 109 & 4538 & 4538 \\
Upahar & 300.0 & 0.50 & 880.0 & 712.0 & 8.75 & 45 & 70 & 70 & 112 & 112 & 5052 & 5052 \\
Arun-4 & 233.0 & 0.50 & 784.0 & 665.7 & 8.93 & 48 & 63 & 63 & 100 & 100 & 4052 & 4052 \\
\hline
\end{tabular}

Sim. - Simulated, Obs.- Observed

Similarly, in the case of rice also the simulated anthesis days and days to physiological maturity were accurately close with the observed values for all the three varieties. For Sunaulo Sugandh and Masuli, grain yield was also accurately close to observed ones. However, the simulated grain yield was underestimated than observed values in case of Prithivi. 
Table 2. Estimated genetic coefficients of rice varieties Prithivi, Sunaulo Sugandh and Masuli under different $\mathrm{N}$-levels during 2008 in Rampur

\begin{tabular}{|c|c|c|c|c|c|c|c|c|c|c|c|c|c|c|}
\hline \multirow[t]{2}{*}{ Cultivars } & \multicolumn{8}{|c|}{ Genetic coefficients } & \multicolumn{2}{|c|}{$\begin{array}{l}\text { Anthesis } \\
\text { day }\end{array}$} & \multicolumn{2}{|c|}{$\begin{array}{l}\text { Physiological } \\
\text { maturity day }\end{array}$} & \multicolumn{2}{|c|}{$\begin{array}{l}\text { Grain yield } \\
\text { (kg/ha) }\end{array}$} \\
\hline & $\mathrm{P} 1$ & P2R & P5 & $\mathrm{P} 2 \mathrm{O}$ & G1 & $\mathrm{G} 2$ & G3 & G4 & Sim. & Obs. & Sim. & Obs. & Sim. & Obs. \\
\hline Prithivi & 470.0 & 110.0 & 350 & 10.0 & 80 & 0.0250 & 0.78 & 1.0 & 74 & 74 & 104 & 104 & 5736 & 5754 \\
\hline $\begin{array}{l}\text { Sunaulo } \\
\text { Sugandh }\end{array}$ & 658.0 & 232.0 & 220 & 10.0 & 43 & 0.0231 & 1.0 & 1.0 & 112 & 112 & 145 & 145 & 4469 & 4469 \\
\hline Masuli & 720.7 & 186.1 & 251 & 10.2 & 45 & 0.0178 & 1.0 & 1.0 & 103 & 103 & 134 & 134 & 3792 & 3892 \\
\hline
\end{tabular}

Sim. - Simulated, Obs.- Observed

\section{Model validation}

Observation on anthesis days and physiological maturity days, $\mathrm{LAI}_{\max }$, unit weight of grain, tops weight at maturity and grain yield were used for the model validation. The validation results showed that both the CERES-Maize and CERES-Rice models could be safely used as a assistant tools for simulation of different agronomic parameters including nitrogen management and resource use efficiency.

\section{Maize}

Simulation results in maize showed good agreement between observed and predicted maximum LAI (RMSE of 0.28 and D-index of 0.89), anthesis days (RMSE $=0.82$ days and D-index $=0.98$ ), maturity days $(\mathrm{RMSE}=1.16$ days and D-index $=0.99)$, and grain yield $(\mathrm{RMSE}=229.89 \mathrm{~kg} / \mathrm{ha}$, and D-index $=$ 0.94) (Fig. 1). Similarly, unit weight of grain (RMSE of 0.01g and D-index of 0.79) was well simulated with observed value. However, tops wt at maturity showed fairly satisfactory agreement (RMSE = $5437.15 \mathrm{~kg} / \mathrm{ha}$ and D-index $=0.48$ ) between observed and predicted values as simulated values were under predicted to all observed yields. Some of the discrepancy might be due to the variations in initial soil nitrogen status indicating low to moderate soil fertility as it was found in the research field.
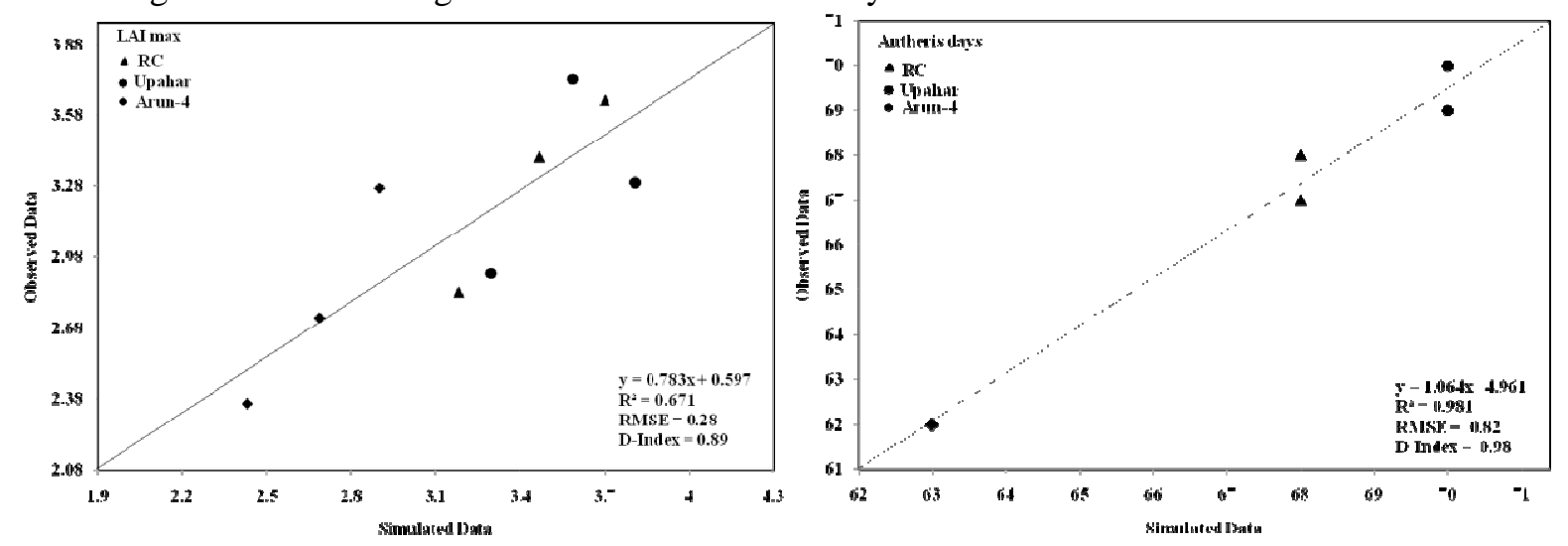

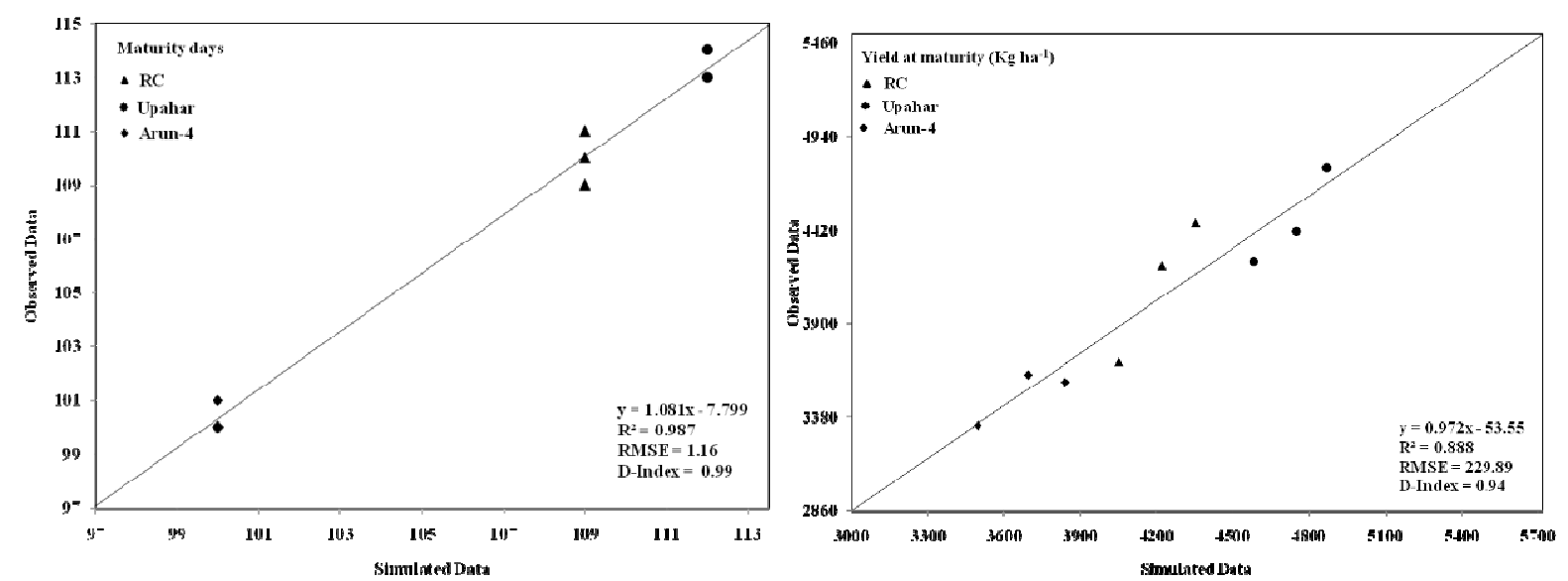

Figure 1: Simulated and observed $\mathrm{LAI}_{\max }$, anthesis days, maturity days, and grain yield $(\mathrm{kg} / \mathrm{ha})$ for three maize cultivars

\section{Rice}

The grain weight (wt unit ${ }^{-1}$ ) was generally well simulated with RMSE of $0.001 \mathrm{~g}$ and D-index of 0.95 . Similarly, good agreement between observed and predicted anthesis days (RMSE $=1.10$ days and Dindex $=0.99)$, maturity days $($ RMSE $=1.97$ days and D-index $=0.99)$, and grain yield $(\mathrm{RMSE}=718.32$ $\mathrm{kg} /$ ha, and D-index $=0.83$ ) were observed (Fig. 2) in rice. In spite of these results, tops wt at maturity $(\mathrm{RMSE}=2559.72 \mathrm{~kg} / \mathrm{ha}$ and $\mathrm{D}$-index $=0.37)$ and $\mathrm{LAI}_{\max }(\mathrm{RMSE}=1.16$ days and $\mathrm{D}$-index $=0.52)$ were shown fairly satisfactory agreement between observed and predicted values. The tops wt at maturity was under-predicted in most of the treatment whereas the maximum LAI was over- predicted.
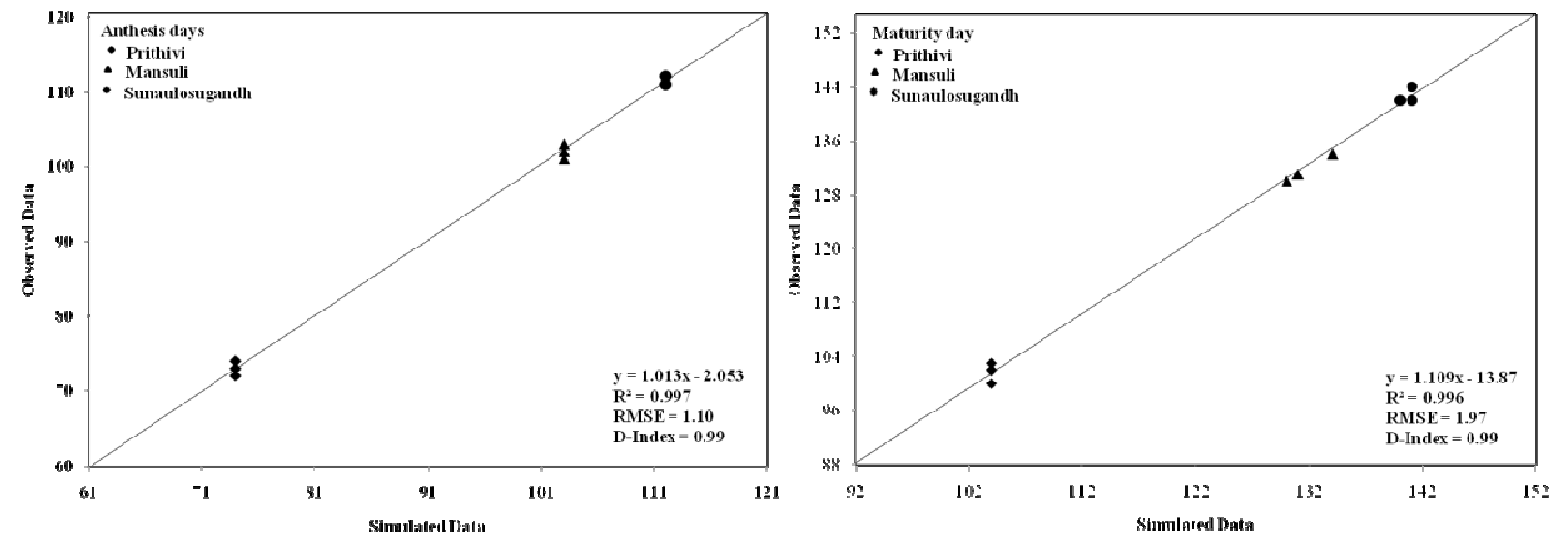

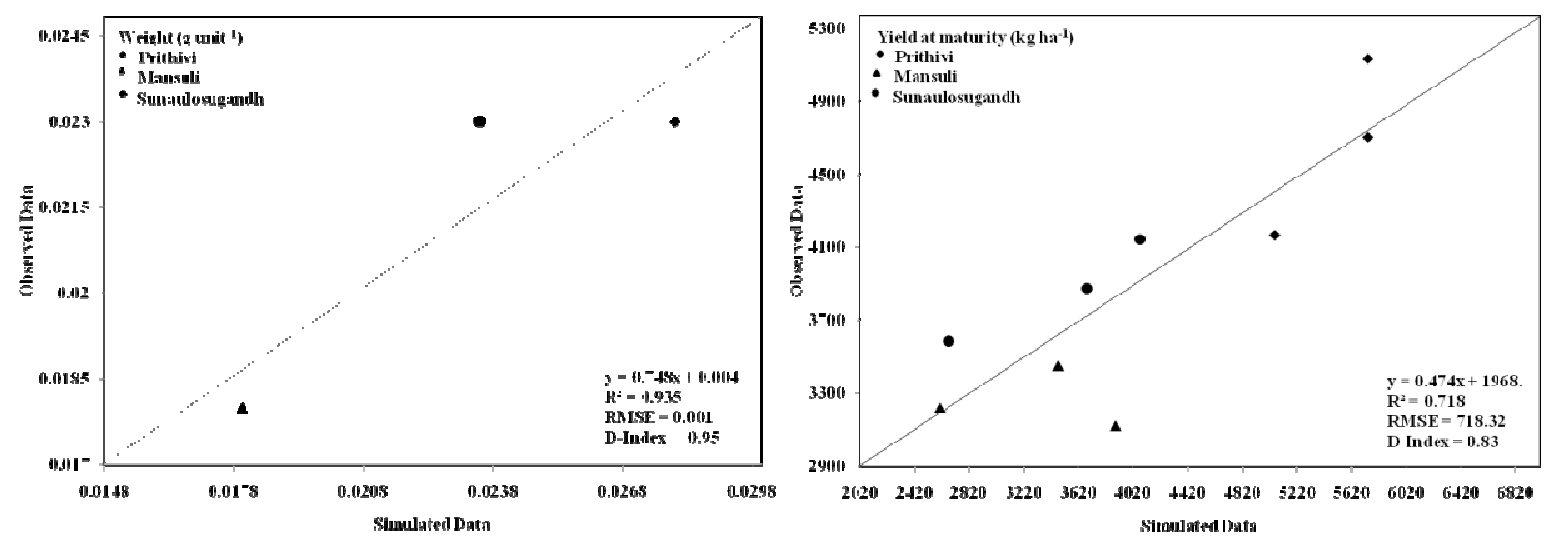

Figure 2: Simulated and observed anthesis days, maturity days, unit weight (g) and grain yield (kg /ha) for three rice cultivars

\section{Nitrogen dynamics}

Nitrogen is a critical element for plant growth and plant response to added nitrogen $(\mathrm{N})$ has proven to be a valuable agronomic practice. Its availability in sufficient quantity throughout the growing season is essential for optimum crop growth (Reddy, 2009).

\section{Maize}

The simulated yield loss under $\mathrm{N}$ stress condition was higher in comparison with $\mathrm{N}$ application. Nitrogen stress limits cell division, chloroplast development, enzymes activity and reduced dry matter yields (Gardner et al., 1985). Higher yield under higher $\mathrm{N}$ application was due to higher uptake of $\mathrm{N}$ by plants (Table 3). Carlone and Russell (1987) reported that grain yield increase by $78.1 \%$ as nitrogen rate was increased from 0 to $80 \mathrm{~kg} / \mathrm{ha}$ in maize. Nitrogen application greatly affected the above-ground dry matter production and the amount partitioned to the kernels, but there was mostly no additional benefit in the application of $\mathrm{N}$ above $90 \mathrm{~kg}$ /ha on grain yield. Furthermore, higher amount of loss of $\mathrm{N}$ (i.e. 2.34$273.37 \%$ more by N-leaching and $200-150 \%$ more by $\mathrm{N}$-denitrification) was under advanced dose of $\mathrm{N}$ applied compared to no $\mathrm{N}$ application. The routes of $\mathrm{N}$-loss were leaching and denitrification, in turn; leaching loss was more against denitrification loss under non-flooded condition (Table 3). Nitrogen losses by leaching and denitriification generally become problem only when nitrogen fertilization exceeds the amount needed to fill the gap between crop uptake needs and the supply from these other sources (Brady and Weil, 2002). 
Table 3. Sensitivity of simulated yield, $\mathrm{N}$-uptake, and $\mathrm{N}$ losses in maize to dose and timing of fertilizer application

\begin{tabular}{|c|c|c|c|c|c|c|c|c|}
\hline $\begin{array}{c}\text { Dose of } \\
N(\mathrm{~kg} / \mathrm{ha})\end{array}$ & $\begin{array}{l}\text { Timing of } N \\
\text { application }\end{array}$ & Varieties & $\begin{array}{c}\text { Simulated } \\
\text { Yield } \\
\text { (kg/ha) }\end{array}$ & $\begin{array}{l}\% \text { yield } \\
\text { change }\end{array}$ & $\begin{array}{c}\text { N } \\
\text { Uptake } \\
\text { (kg/ha) }\end{array}$ & $\begin{array}{c}\mathrm{N} \\
\text { Leached } \\
(\mathrm{kg} / \mathrm{ha})\end{array}$ & $\begin{array}{c}\text { N Volatilized } \\
(\mathrm{kg} / \mathrm{ha})\end{array}$ & $\begin{array}{c}\mathbf{N} \\
\text { Denitrified } \\
(\mathrm{kg} / \mathrm{ha})\end{array}$ \\
\hline \multirow[t]{3}{*}{$90 *$} & $45 \mathrm{~kg} \mathrm{~N} / \mathrm{ha}$ (basal) + & R.Composite & 4353 & 100.00 & 127.77 & 13.00 & 1.00 & 0.05 \\
\hline & $45 \mathrm{~kg} \mathrm{~N} / \mathrm{ha}(32 \mathrm{DAS})$ & Upahar & 4874 & 100.00 & 128.31 & 13.52 & 1.50 & 0.06 \\
\hline & & Arun-4 & 3841 & 100.00 & 117.61 & 16.56 & 1.50 & 0.04 \\
\hline \multirow[t]{3}{*}{0} & $0 \mathrm{~kg} \mathrm{~N} / \mathrm{ha}$ & R.Composite & 1610 & 36.99 & 42.13 & 9.19 & 0.00 & 0.05 \\
\hline & & Upahar & 1796 & 36.85 & 42.59 & 9.82 & 0.00 & 0.06 \\
\hline & & Arun-4 & 1459 & 37.98 & 38.33 & 7.51 & 0.00 & 0.03 \\
\hline \multirow[t]{3}{*}{45} & $22.5 \mathrm{~kg} \mathrm{~N} / \mathrm{ha}$ (basal) + & R.Composite & 3181 & 73.01 & 85.18 & 9.55 & 0.50 & 0.04 \\
\hline & $22.5 \mathrm{~kg} \mathrm{~N} / \mathrm{ha}(32$ & Upahar & 3418 & 70.13 & 85.73 & 10.05 & 0.40 & 0.04 \\
\hline & DAS) & Arun-4 & 3537 & 92.08 & 80.80 & 8.77 & 0.50 & 0.03 \\
\hline \multirow[t]{3}{*}{135} & $67.5 \mathrm{~kg} \mathrm{~N} / \mathrm{ha}$ (basal) & R.Composite & 4386 & 100.76 & 145.01 & 29.90 & 1.80 & 0.10 \\
\hline & $+67.5 \mathrm{~kg} \mathrm{~N} / \mathrm{ha}(32$ & Upahar & 4943 & 101.42 & 156.24 & 28.56 & 1.75 & 0.09 \\
\hline & DAS) & Arun-4 & 3844 & 100.08 & 119.86 & 28.04 & 1.60 & 0.06 \\
\hline
\end{tabular}

$* 90 \mathrm{~kg} \mathrm{~N} / \mathrm{ha}$ as a standard treatment

\section{Rice}

Grain yield was increased significantly with nitrogen application (Table 4). This might be attributed to the significant effect of nitrogen on chlorophyll formation, photosynthesis and assimilate production that resulted in optimum production of yield components which had direct bearing on the final grain yield. Reddy and Reddi (2005) reported that leaf expansion depends upon N supply, whereas high nitrogen application leads to development of larger leaves. Leaves are the primary organ for solar radiation interception and photosynthesis. As the leaf area index increases, light interception is more resulting in higher dry matter production and grain yield.

Nitrogen was lost through leaching, volatilization and denitrification under the flooded paddy soil condition. Amount of loss in higher dose of $\mathrm{N}$-application was $18-165 \%, 1-48 \%$ and $22.10-667.3 \%$ more against no $\mathrm{N}$-application condition through leaching, volatilization and denitrification, respectively (Table 4). In this trial due to unavailability of water for continuous flooding, given the alternate wetting and drying condition and this sorts of irrigation resulted the higher loss of $\mathrm{N}$ by denitrification. When soil becomes water logged, $\mathrm{O}_{2}$ is excluded and anaerobic conditions occur as some anaerobic organisms obtain their $\mathrm{O}_{2}$ from $\mathrm{NO}_{2}$ and release of $\mathrm{N}_{2}$ and $\mathrm{N}_{2} \mathrm{O}$. It was reported that about $80 \%$ of the applied $\mathrm{NO}_{3}{ }^{-}$ was lost in 72 hours due to denitrification (Prasad and Lakhdive, 1969).

Table 4. Sensitivity of simulated yield, N-uptake, and $\mathrm{N}$ losses in rice to dose and timing of fertilizer application

\begin{tabular}{|c|c|c|c|c|c|c|c|c|}
\hline $\begin{array}{l}\text { Dose of } \\
\mathrm{N}(\mathrm{kg} / \mathrm{ha})\end{array}$ & $\begin{array}{l}\text { Timing of } \mathrm{N} \\
\text { application }\end{array}$ & Varieties & $\begin{array}{c}\text { Simulated } \\
\text { Yield } \\
(\mathrm{kg} / \mathrm{ha}) \\
\end{array}$ & $\begin{array}{l}\% \text { yield } \\
\text { change }\end{array}$ & $\begin{array}{c}\text { N Uptake } \\
(\mathrm{kg} / \mathrm{ha})\end{array}$ & $\begin{array}{l}\text { N Leached } \\
\text { (kg/ha) }\end{array}$ & $\begin{array}{l}\text { N Volatilized } \\
\text { (kg/ha) }\end{array}$ & $\begin{array}{l}\text { N Denitrified } \\
(\mathrm{kg} / \mathrm{ha})\end{array}$ \\
\hline \multirow[t]{3}{*}{$120 *$} & $60 \mathrm{~kg} \mathrm{~N} / \mathrm{ha}$ & Prithivi & 5736 & 100.00 & 104.83 & 1.16 & 10.16 & 58.27 \\
\hline & (basal)+30 kg N/ha & Mansuli & 3892 & 100.00 & 170.53 & 1.16 & 10.18 & 32.91 \\
\hline & $\begin{array}{l}(35 \mathrm{DAS})+30 \mathrm{~kg} \\
\mathrm{~N} / \mathrm{ha}(\text { at PI stage) }\end{array}$ & $\begin{array}{c}\text { Sunaulosuga } \\
\text { ndh }\end{array}$ & 4082 & 100.00 & 179.42 & 1.16 & 11.17 & 30.59 \\
\hline \multirow[t]{3}{*}{0} & $0 \mathrm{~kg} \mathrm{~N} / \mathrm{ha}$ & Prithivi & 2112 & 36.82 & 41.07 & 0.00 & 2.00 & 10.72 \\
\hline & & Mansuli & 1514 & 38.90 & 59.68 & 0.00 & 2.50 & 9.81 \\
\hline & & $\begin{array}{c}\text { Sunaulosuga } \\
\text { ndh }\end{array}$ & 1638 & 40.13 & 62.88 & 0.00 & 3.75 & 10.47 \\
\hline \multirow[t]{3}{*}{40} & $20 \mathrm{~kg} \mathrm{~N} / \mathrm{ha}$ & Prithivi & 5360 & 93.44 & 96.92 & 0.18 & 5.01 & 13.09 \\
\hline & (basal)+10 kg N/ha & Mansuli & 2649 & 68.06 & 104.46 & 0.17 & 4.85 & 13.30 \\
\hline & $(35 \mathrm{DAS})+10 \mathrm{~kg}$ & Sunaulosuga & 2682 & 65.70 & 107.68 & 0.17 & 6.33 & 13.95 \\
\hline
\end{tabular}


N/ha (at PI stage) $40 \mathrm{~kg} \mathrm{~N} / \mathrm{ha}$
(basal) $+20 \mathrm{~kg} \mathrm{~N} / \mathrm{ha}$

(35 DAS) $+20 \mathrm{~kg}$

$\mathrm{N} / \mathrm{ha}$ (at PI stage)

$80 \mathrm{~kg} \mathrm{~N} / \mathrm{ha}$

160

(basal)+40 kg N/ha

(35 DAS) $+40 \mathrm{~kg}$

$\mathrm{N} / \mathrm{ha}$ (at PI stage)

$\begin{array}{cc}\text { ndh } & \\ \text { Prithivi } & 5736 \\ \text { Mansuli } & 3468 \\ \text { Sunaulosuga } & 3628 \\ \text { ndh } & \\ \text { Prithivi } & 5736 \\ \text { Mansuli } & 3892 \\ \text { Sunaulosuga } & 4469\end{array}$

$\begin{array}{cccc}100.00 & 104.83 & 0.67 & 7.06 \\ 89.10 & 146.94 & 0.67 & 5.50 \\ 88.88 & 150.04 & 0.67 & 6.26 \\ & & & \\ 100.00 & 104.83 & 1.65 & 10.43 \\ 100.00 & 172.35 & 1.65 & 11.80 \\ 109.48 & 198.50 & 1.65 & 12.66\end{array}$

32.76

17.33

17.55

82.29

57.71

49.20

*120 kg N/ha as a standard treatment; PI stage: panicle initiation stage

\section{Conclusion}

Good to fairly satisfactory agreement between the observed and simulated values of anthesis days, days to maturity, $\mathrm{LAI}_{\max }$, unit wt $(\mathrm{g})$, tops wt at maturity $(\mathrm{kg} / \mathrm{ha})$ and grain yield $(\mathrm{kg} / \mathrm{ha})$ conform that the models are well validated under the subtropical condition of southern central Nepal. Sensitivity study also showed that the route of $\mathrm{N}$-loss and magnitude is higher under the flooded rice field condition as compared to non-flooded maize field. So, it requires more intensive $\mathrm{N}$-management in rice field for obtaining higher nitrogen use efficiency. For wider application of models, they need to be worked with well collected full datasets so that the results have wider application with greater precision.

\section{Acknowledgements}

The first two authors are highly accorded to NARDF for providing financial supports for the accomplishment of their master thesis. NMRP is thanked for providing agro-meteorological data sets to run the model. The authors like to express special thank to Soil Science Division, NARC, Khumaltar for estimating the routine soil analysis and other nutrient parameters required to run the model. Thanks also go to Dr. S.K. Sah, Dr. N.R. Devkota, Dr. J. Timsina and Dr. Gerrit Hoogenboom for their inspiration and continuous guidelines to run the model.

\section{References}

Amgain, LP and J Timsina. 2007. Simulation of yield, water and nitrogen balances in rice in Punjab, using CSMCERES-Rice model. J Inst. Agric. Anim. Sci. 28:15-26

Amgain, LP and J Timsina. 2005. Major agronomical research work at the Institute of Agriculture and Animal Sciences, Rampur, Chitwan, Nepal: A Review. J. inst. Agric. Anim. Sci. vol 25:1-22

Amgain, LP., NR Devkota, J Timsina and B Singh. 2006. Effect of climate change and CO2 concentration on growth and yield of rice wheat in Punjab: Simulations using CSM-CERES-Rice and CSM-CERES-Wheat models. J. Inst. Agric. Anim. Sci. 27:103-110.

APP. 1995. Agricultural Perspective of Nepal 1994-2014.

Asadi, ME and RS Clement. 2003. Evaluation of CERES-Maize of DSSAT model to simulate nitrate leaching, yield and soil moisture content under tropical conditions. J. Food and Agri. Eng. Res. 1(3/4): 270-276.

Bhusal TN, LP Amgain, SK Sah and NR Devkota. 2008. Effect of weather years, CO2 and climate change on yield of open pollinated varieties of maize at Rampur, Chitwan. Paper presented at the 5th National Conference on Science and Technology, Nepal Academy of Science and Technology (NAST) held on 10-12 November, 2008 in Kathmandu, Nepal.

Brady, NC and RR Weil. 2002. The nature and properties of soils (13th ed.). Pearson Education (Singapore) Pte. Ltd., Indian branch, New Delhi, 621p.

Carlone, MR and WA Rusell. 1987. Response to plant densities and nitrogen level for four maize cultivars. Crop Sci. 27(3): 165-470.

De Datta, SK. 1984. Availability and management of nitrogen in low land rice in relation to soil characteristic. Workshop on "Characterization, classification and utilization of wetland soils" manual. IRRI, Manila, Philippines.

FAOSTAT. 2007. World wheat, corn and rice production, 2007. FAO, Rome, Italy 
Gardner, FP, RB Pearce and RL Mitchell. 1985. Physiology of crop plants. Iowa State University Press. Ames.

Gurung, DB. 2010. National Co-ordinator report on maize. Paper presented in the 26th Summer Crops Workshop at Rampur, Chitwan in Nepal (March 3- 5, 2010)

Lamsal, A, LP Amgain and TN Bhusal. 2010. Growth and yield performance of rice cultivars under graded level of nitrogen and simulation results under changing climatic scenarios by using CSM-CERES-Rice Model in Chitwan. Paper accepted for IAAS J vol 31.

MoA/C. 2008/09. Statistical Information on Nepalese Agriculture. Government of Nepal, Ministry of Agriculture and Cooperatives, Agri-Business Promotion and Statistics Division, Singh Durbar, Kathmandu, Nepal

Pathak, H, A Bhatia, S Prasad, S Singh, S Kumar, MC Jain and U Kumar. 2002. Emission of nitrous oxide from rice-wheat systems of indo-gangetic Plains of India. Environmental Monitoring and Assessment, 77:163178

Prasad, R and BA Lakhdive. 1969. Nitrification of ammonia sulphate and subsequent losses of $\mathrm{N}$ under water logged condition as affected by nitrification inhibitor N-serve. Indian J. Agric. Sci. 39:259-262.

Reddy, SR. 2009. Agronomy of field crops. Kalyani Publishers, Third Revised Edition. Kalyani Publishers, Ludhiana, India. pp. 9-124

Reddy, TY. and GH Reddi. 2005. Principles of agronomy., Kalyani Publishers, Ludhiana, India. pp. 54-326.

Sapkota, A, LP Amgain, NR Devkota and J Timsina. 2008. Evaluation of CSM-CERES-Maize model, estimation of potential yield and yield gap analysis of winter maize at Rampur, Chitwan. J. Inst. Agric. Anim. Sci. 29: 27-32.

Sah, ML. 2010. National Co-ordinator report on rice. Paper presented in the 26th Summer Crops Workshop at Rampur, Chitwan in Nepal (March 3- 5, 2010).

Timsina, J, ML Jat, and K Majumdar. 2010. Rice-maize systems of South Asia: current status, future prospects and research priorities for nutrient management. Plant Soil DOI 10.1007/s11104-010-0418-y

Timsina, J, and DJ Connor. 2001. Productivity and management of rice-wheat cropping systems: issues and challenges. Field crops research.69:93-132.

Timsina, J, H Pathak, E Humphreys, D Godwin, B Singh, AK Shukla, and U Singh. 2004. Evaluation of, and yield gap analysis in rice using, CERES Rice ver. 4.1 in northwest India. Abstract of the 4th International Crop Science Congress, Brisbane, Australia, 26 Sept.-1 Oct. 2004. 170p.

Watanabe, I and S Mitsui. 1979. Denitrification loss of fertilizer nitrogen in paddy soils - its recognition and impact. Res. Paper Ser. No. 37, Int Rice Res Inst, Los Banos, Philippines. 